Krystyna Mihułka

Uniwersytet Rzeszowski

\title{
KOMPONENT KULTUROWY A PROCES PRZYSWAJANIA JĘZYKA OBCEGO
}

\begin{abstract}
A cultural component in the process of foreign language acquisition
The aim of this article is to draw attention to the significance of a cultural component in the process of acquiring a foreign language. Presenting and discussing the definitions of cultural competence, the author of this article calls for the permanent inclusion of cultural competence in a foreign language lesson during which it could undergo constant development. Moreover, the author provides various interpretations of the term 'knowledge of the foreign language' laying particular emphasis on its colloquial and academic usage.
\end{abstract}

\section{Wprowadzenie}

Kierownik ds. Marketingu

Opis stanowiska: (...)

Wymagania:

- Min. 5-letnie doświadczenie na samodzielnym stanowisku w marketingu (...)

- Dobra znajomość jezzyka angielskiego [podkr. KM]

- $(\ldots)^{1}$

Wymagania stawiane osobom ubiegającym się o to stanowisko, przynajmniej w kwestii znajomości języka obcego, są w mojej opinii zbyt powierzchownie sformułowane i tak naprawdę nie wiadomo, czego przyszły pracodawca będzie oczekiwał od swojego potencjalnego pracownika. Z oferty nie można

\footnotetext{
${ }^{1}$ http://www.pracuj.pl/praca/kierownik-ds.-ma (DW 5.10.2012).
} 
wyczytać, ani o jaką (w sensie poziomu zaawansowania językowego) znajomość języka (powszechnie używanego czy może specjalistycznego) chodzi, ani tego czy komunikacja przebiegająca przy jego pomocy będzie odbywała się tylko z rodzimymi użytkownikami, czy być może także z kontrahentami z innych krajów, dla których ów język jest również językiem obcym. Nie wiadomo zatem, czy aplikant powinien znać język obcy w stopniu umożliwiającym w miarę poprawną komunikację pozwalającą na ogólne rozumienie komunikatów nadawcy i werbalizację swoich własnych intencji komunikacyjnych, czy może oprócz umiejętności stricte językowych powinien wykazać się świadomością różnic kulturowych, umiejętnością wychwytywania ich podczas komunikacji, wyjaśniania ich podłoża oraz przyczyn możliwych nieporozumień (inter)kulturowych. I tak np. podczas spotkania z przedstawicielami pewnej firmy z Danii przebiegającego w języku angielskim, dodajmy że w przyjemnej, wręcz przyjacielskiej atmosferze, do zadań osoby znającej ten język będzie należało nie tylko tłumaczenie rozmów, ewentualnie samodzielne prowadzenie pertraktacji, lecz także wyjaśnienie polskiemu szefowi, dlaczego Duńczycy nie podadzą mu ręki na pożegnanie, jak i dlaczego on nie powinien tego zrobić. Ten z pozoru mało znaczący gest może spowodować, że pomyślnie przebiegające rozmowy handlowe mogą i tak zakończyć się fiaskiem².

Co zatem rozumie się pod pojęciem znajomość języka obcego? Gdy zapytamy przeciętnego ucznia o to, czy zna jakiś język obcy, usłyszymy niejednokrotnie, że tak, przy czym jest to najczęściej język angielski. Wyniki badań opinii publicznej wypadają podobnie, gdyż prawie połowa ankietowanych pełnoletnich (najczęściej młodych) Polaków może pochwalić się znajomością co najmniej jednego języka obcego ${ }^{3}$. W czasach nasilonej migracji mającej różne, nie tylko zarobkowe, podłoże, przytaczane "fakty" powinny napawać optymizmem i utwierdzać w przekonaniu, że w materii nauczania języków obcych osiągnęliśmy w Polsce ogromny sukces $i$ że w zasadzie nie trzeba już niczego zmieniać i ulepszać. Można by faktycznie spocząć na laurach, jeśliby nie inne dane pochodzące z badań przeprowadzonych wśród osób, którym przyszło mieszkać poza granicami naszej ojczyzny i którzy zmuszeni byli do posługiwania się językiem dla nich obcym. Wyniki raportu ministra pracy dotyczące aktywności zawodowej Polaków w krajach Unii Europejskiej pokazują, że „największe problemy Polakom za granicą sprawia wciąż język. Przez to zatrudniają

\footnotetext{
${ }^{2}$ Podanie ręki (na pożegnanie, czy na powitanie) jest w Niemczech (w Polsce) postrzegane jako przejaw sympatii i bliskości. W Danii wręcz przeciwnie, używane jest przede wszystkim w sytuacjach formalnych i sygnalizuje tym samym pewien dystans (Liedtke, 2006: 158).

${ }^{3}$ W 2006 roku aż 45 procent ankietowanych Polaków deklarowało znajomość jednego z języków obcych w stopniu umożliwiającym porozumiewanie się (CBOS BS/177/2006).
} 
się na posadach poniżej kwalifikacji, nie potrafią korzystać z oficjalnych informacji o legalnej pracy. Nie mają dostatecznej wiedzy o warunkach pracy i życia w kraju, do którego trafiają" (Adamowska, 2006: 4). Przytoczone wyżej spostrzeżenia potwierdzają częściowo informacje uzyskane od znajomych pracujących za granicą (w Anglii, Niemczech), którzy nierzadko podkreślali, że ciężko im dogadać się z tubylcami. Trudności w kontaktach z rodzimymi użytkownikami języka wynikały nie tyle z niedostatecznego opanowania przez nich struktur stricte językowych (część badanych to absolwenci kierunków filologicznych), ile z problemów w odnalezieniu się w nowej, innej rzeczywistości. U ich podstaw leżą powierzchowna znajomość obcej kultury, nieświadomość różnic kulturowych, słabo rozwinięta wrażliwość na inność, czego następstwem jest niewielka zdolność adaptacyjna w nowym środowisku.

Analiza przywołanych wyników i stwierdzeń pozwala na jednoznaczną konkluzję - deklarowana znajomość języka obcego nie do końca pokrywa się z praktycznymi umiejętnościami respondentów, o czym świadczy wynik najważniejszego sprawdzianu, jakim jest bezpośrednia konfrontacja z native speakerami. Deklarowana znajomość języka nie odzwierciedla więc faktycznej umiejętności posługiwania się nim w środowisku naturalnym, a tylko przeświadczenie o tym, że skoro uczęszczamy na lekcje z języka obcego kilka, czasem nawet kilkanaście lat, to znamy ten język doskonale. Widać więc, że potoczna interpretacja zwrotu znajomość języka obcego znacznie różni się od tej prezentowanej na łamach literatury przedmiotu, gdzie także zaskakuje mnogość definicji. Wynika ona przede wszystkim z obowiązujących w różnych przedziałach czasowych metod nauczania języków obcych, których powstawanie uwarunkowane było w dużej mierze sytuacją społeczną w danym kraju i na świecie oraz potrzebami i oczekiwaniami obywateli. Cele stawiane w poszczególnych metodach rzutowały więc w bezpośredni sposób na rozumienie zwrotu znajomość języka obcego. Podczas gdy w metodzie gramatyczno-tłumaczeniowej opanowanie języka obcego równoznaczne było ze znajomością reguł gramatycznych typowych dla danego języka oraz umiejętnością zastosowania ich w praktyce podczas rozumienia tekstu czytanego, tłumaczenia obcojęzycznych tekstów literackich na język ojczysty oraz pisania w języku obcym, tak w metodzie audiolingwalnej tylko taka osoba mogła pochwalić się znajomością języka obcego, która wykształciła $w$ trakcie jego nauki odpowiednie nawyki językowe, a więc trwałe związki pomiędzy bodźcem a reakcją, odzwierciedlające się w opanowaniu czterech sprawności językowych w kolejności: słuchanie/mówienie oraz czytanie/ pisanie. Metoda kognitywna zakładająca pełne zaangażowanie świadomości uczniów w proces przyswajania języka obcego uznawała za cel nauki wykształcenie kompetencji językowej. Osoba znająca język obcy potrafi zatem wykorzystując pewną skończoną liczbę reguł gramatycznych rozumieć i samodzielnie 
tworzyć nieskończoną ilość poprawnych zdań dotychczas nigdy niesłyszanych ani nieczytanych. W podejściu komunikacyjnym, obecnie najpowszechniejszym w Polsce, celem nauczania języka obcego jest osiągnięcie kompetencji komunikacyjnej rozumianej jako umiejętność efektywnego porozumiewania się w sposób adekwatny do danej sytuacji komunikacyjnej. Na lekcji języka obcego należy więc w pierwszej kolejności zająć się rozwijaniem czterech sprawności językowych (słuchanie, mówienie, czytanie, pisanie) oraz umiejętności zastosowania ich w naturalnych sytuacjach komunikacyjnych. Przekazywanie wiedzy językowej i kulturoznawczej przesunięto na dalszy plan.

Zdaniem Komorowskiej (2005a) osobę, która może pochwalić się znajomością języka obcego powinna charakteryzować kompetencja komunikacyjna i lingwistyczna. Ta pierwsza rozumiana jest jako „umiejętność skutecznego zdobywania i przekazywania informacji w mowie i piśmie w sposób poprawny i odpowiedni w danej sytuacji" (2005a: 9). Kompetencja lingwistyczna definiowana jest przez cytowaną autorkę jako „umiejętność rozumienia przez daną osobę nieskończenie wielu zdań, także takich, których ona nigdy przedtem nie słyszała jak i umiejętność budowania nieskończenie wielu poprawnych zdań, w tym takich, których ona nigdy jeszcze $w$ tej formie nie wypowiedziała" (2005a: 9). Wspomniane kompetencje określane są przez Komorowską mianem podstawowych umiejętności, jakimi powinni dysponować użytkownicy danego języka.

Jednak gdy przyjrzymy się przedstawionym wyżej wynikom raportu oraz doświadczeniom osób przebywających za granicą zauważymy, że dysponowanie tylko kompetencją językową i komunikacyjną to za mało, aby móc $w$ pełni uczestniczyć w komunikacji z przedstawicielami odmiennych kultur. Słabo rozwinięta kompetencja interkulturowa (może nawet jej brak) stała się główną przyczyną frustracji, u której podstaw leżały niepowodzenia komunikacyjne opisywanych osób. Celem niniejszego artykułu jest zatem podkreślenie ważności komponentu kulturowego, a co za tym idzie kompetencji interkulturowej, w procesie nauczania i uczenia się języka obcego. W publikacji tej dokonano przeglądu wybranych definicji kompetencji interkulturowej uwzględniając ich elementy wspólne i różnice oraz zwrócono uwagę na nierozerwalny związek języka i kultury.

\section{Kompetencja interkulturowa - przegląd definicji}

W literaturze przedmiotu znaleźć można wiele definicji oraz prób zdefiniowania kompetencji interkulturowej, które różnią się przede wszystkim stopniem szczegółowości opisu jej istoty. $Z$ jednej strony mamy do czynienia z 
lakonicznymi ujęciami kompetencji interkulturowej, w których przedstawiana jest ona jako zbiór umiejętności lepszego zrozumienia siebie i innych, z drugiej zaś z definicjami wręcz drobiazgowymi ukazującymi wspomnianą kompetencję nie w sposób holistyczny, lecz odnoszący się do jej trzech przenikających się płaszczyzn - wiedzy, postaw i umiejętności.

Inny podział istniejących definicji kompetencji interkulturowej wynika z przekonania, że jej rozwój odbywa się niezależnie od języka lub jest właśnie przez ten język determinowany i stymulowany. Patrząc na kompetencję interkulturową przez pryzmat procesu przyswajania języka obcego, nie można postrzegać jej jako kompetencji uniwersalnej rozwijającej się niezależnie od języka docelowego i odzwierciedlonej w nim kultury, lecz wręcz przeciwnie jako kompetencję, której rozwój warunkuje kompetencja językowa w zakresie danego języka obcego oraz opanowanie ogólnych reguł kompetencji komunikacyjnej. Kompetencja interkulturowa kształtująca się w oderwaniu od języka obcego nie może rozwinąć się w pełni. O takim stopniu rozwoju można mówić tylko wówczas, gdy zdobytą wiedzę oraz nabyte postawy wobec innych będzie można "wypróbować" w działaniu komunikując się z przedstawicielami innego obszaru kulturowego. Podczas gdy zarówno zdobywanie wiedzy na temat obcej i własnej kultury może odbywać się w języku ojczystym, jak i wykształcanie postaw przebiegać w oderwaniu od języka, bazując tylko na obserwacji, doświadczeniu i dotychczas zgromadzonej wiedzy, tak połączenie wiedzy i postaw oraz ich użycie w trakcie interakcji przebiegającej w kontekście interkulturowym jest praktycznie niemożliwe bez zastosowania odpowiednich dla danej sytuacji strategii komunikacyjnych, wzorców komunikacyjnych, skutecznych strategii rozwiązywania konfliktów etc. Bez znajomości języka obcego uczestnik komunikacji mógłby w najlepszym wypadku stosować i poprawnie interpretować tylko sygnały niewerbalne i parawerbalne, które stanowią ważną część komunikacji interkulturowej, jednak nie mogą zastąpić werbalnego przekazu (Mihułka, 2012: 35).

Jednoznaczne zdefiniowanie kompetencji interkulturowej wydaje się rzeczą wręcz niemożliwą. Co więcej stwierdza się coraz częściej, że w zasadzie nie ma ani możliwości ani potrzeby utworzenia wyczerpującego opisu i definicji tej kompetencji. Byram (2005: 59) proponuje, aby skupić się na charakterystyce tych elementów kompetencji interkulturowej, których można nauczać, które można przyswoić i które to mogą stanowić podstawę własnego rozwoju. Volkmann (2002: 44) przestrzega jednak przed tym, aby podczas opisu kompetencji interkulturowej nie koncentrować się tylko na rzeczach powierzchownych i błahych, gdyż wówczas będzie ona postrzegana jedynie jako bag of tricks, co w żadnym wypadku nie oddaje złożoności tego pojęcia. 
Kompetencja interkulturowa bywa postrzegana jako kompleksowa umiejętność czy też zespół zinternalizowanych umiejętności funkcjonowania i radzenia sobie w nowych, trudnych sytuacjach komunikacyjnych przebiegających w kontekście wielokulturowości (Lubecka, 1998: 61; Myczko, 2005: 29; Aleksandrowicz-Pędich, 2006: 11). Inni autorzy przedstawiają kompetencję interkulturową jako sumę wszystkich niezbędnych umiejętności pozwalających stworzyć z przedstawicielami odmiennych obszarów kulturowych stan wspólnoty, który nie byłby zdominowany przez pewne specyficzne pod względem kulturowym cechy i wyobrażenia (Bollmann i inni 1998: 2). Umiejętność ta nie jest jednak nabywana całościowo - najpierw należy krytycznie spojrzeć na uzależnione od własnej kultury myślenie, działanie, zachowanie, a następnie wykształcić umiejętność i gotowość do przejęcia i analizy obcokulturowych perspektyw. Kompetencję interkulturową utożsamiać należy więc z procesem dynamicznym, który nigdy nie dobiega końca. Zdaniem Volkmanna (2002: 12-13) składa się ona z koniecznej wiedzy na temat różnic występujących pomiędzy własną i obcą kulturą oraz z umiejętności rozpoznania tychże różnic w konkretnych sytuacjach, rozwinięcia i zastosowania odpowiednich strategii pozwalających w sposób zautomatyzowany zająć się standaryzacjami występującymi w obrębie tej innej kultury. Chodzi zatem o umiejętność unikania nieporozumień, łagodzenia ewentualnych komplikacji pojawiających się $\mathrm{w}$ trakcie interakcji, a więc o w miarę sprawne i bezproblemowe kształtowanie komunikacji.

Wilczyńska (2005: 22) stwierdza, że nabywanie i rozwijanie kompetencji interkulturowej nie odbywa się „w próżni intelektualno-psychicznej ani w izolacji od innych trwałych dyspozycji danej osoby." W formie wykresu ukazującego zakresy i konteksty wspomnianej kompetencji (2005: 23) zwróciła ona uwagę na szereg elementów mających wpływ na nasze postawy, umiejętności oraz wiedzę. Specjalnie dla potrzeb dydaktyki języka obcego nazwane wielkości scharakteryzowane zostały przez cytowaną autorkę (2005: 22) w następujący sposób: „specyficzna świadomość metakulturowa (obejmująca naturę i mechanizmy funkcjonowania kultury), wrażliwość (inter)kulturowa (pozwalająca rozpoznawać przejawy działań interkulturowych i doszukiwać się odpowiedniej ich interpretacji), umiejętność mediacji interkulturowej (umożliwiająca zrównoważoną interakcję, nastawioną na usuwanie barier komunikacyjnych i wzajemne wzbogacanie się)".

W innej definicji sformułowanej również z perspektywy dydaktyki nauczania języka obcego przez Heyd (1997: 34-35) kompetencja interkulturowa ukazana została jako rodzaj umiejętności pozwalający skutecznie komunikować się w kontekstach obcokulturowych. Wspomniana kompetencja złożona jest zatem z wachlarza umiejętności oraz strategii pozwalających na „rozprawienie 
się" z własnymi i obcokulturowymi fenomenami, jak i interpretowanie/wyjaśnianie obcego świata na bazie własnego i na odwrót. Autorka wymieniła następujące umiejętności wchodzące w skład kompetencji interkulturowej: wielopłaszczyznowe postrzeganie obcokulturowych fenomenów, empatia i krytyczna tolerancja w stosunku do obcej kultury i jej przedstawicieli, rozumienie oczekiwań oraz działań członków obcej kultury, jak również interpretowanie ich z perspektywy charakterystycznej dla tejże wspólnoty kulturowej, rozumienie procesów zachodzących podczas interakcji przebiegającej pomiędzy osobami należącymi do różnych grup kulturowych.

Cechą wspólną wszystkich wyżej przedstawionych definicji jest to, że kompetencja interkulturowa to umiejętność umożliwiająca nam funkcjonowanie w wielokulturowym świecie, w którym kontakty z przedstawicielami innych kultur są na porządku dziennym i w którym od udanej interakcji z nimi uzależnione jest osiąganie uprzednio postawionych celów komunikacyjnych. Wspomnianą kompetencję przedstawiono w przytaczanych definicjach jako kompleksowy zbiór zarówno wiedzy o obcej i własnej kulturze, co najmniej neutralnych postaw wobec innej kultury i jej członków oraz umiejętności i strategii pozwalających na interpretowanie obcych komunikatów jak i formułowanie własnych przy użyciu wzorców i środków komunikacyjnych odpowiednich dla konkretnej sytuacji komunikacyjnej. Wyszczególnienie w obrębie kompetencji interkulturowej trzech płaszczyzn, tj. wiedzy, postaw i umiejętności, pozwalających na lepsze uchwycenie tego złożonego pojęcia stało się przedmiotem licznych badań oraz znalazło odzwierciedlenie w modelach kompetencji interkulturowej ${ }^{4}$.

\section{Kultura a proces przyswajania języka obcego}

Analiza zamieszczonych w niniejszym artykule definicji i przemyśleń pozwala na wyciągnięcie jednoznacznych wniosków, iż nauczanie i uczenie się języka obcego w oderwaniu od kultury, która go przecież ukształtowała, jest pozbawione sensu, gdyż nasza interpretacja zjawisk obcokulturowych będzie niepełna i tak naprawdę wcale nie odda ich głębi. Lekcja języka obcego powinna być zatem zawsze także lekcją o kulturze kraju nauczanego języka. Bredella i Christ (1995: 12) są zdania, że oderwane od kultury, czysto instrumentalne przyswajanie języka obcego jest niemożliwe w przypadku języków

\footnotetext{
${ }^{4}$ Do najbardziej popularnych i najczęściej przytaczanych modeli kompetencji interkulturowej należą modele Byrama (1997) i A. Erll \& M. Gymnich (2007).
} 
naturalnych ${ }^{5}$. Każda osoba ucząca się języka obcego jest „podrażniana” przez tę inną, odzwierciedloną w języku, kulturę oraz musi nauczyć się z nią obchodzić, gdyż sam język do tego zmusza. Lewicki (2005: 248) uważa, że lekcja języka obcego jest zawsze zorientowana na kulturę, bo przecież nierozerwalny związek pomiędzy językiem a kulturą był, jest i pozostanie bezsprzeczny. Uczenie się języków obcych to dla Krumma (1994: 28) szukanie dojścia/dostępu do innej kultury, zaś Göhring (1980: 70) dodaje, że tam gdzie uczymy się języka obcego i gdzie jest on nauczany, tam zawsze chodzi o spotkanie interkulturowe, komunikację interkulturową oraz o proces mający na celu poszerzanie własnego horyzontu kulturowego.

Beirat Deutsch als Fremdsprache des Goethe-Instituts (1992: 550, teza 18) zwraca uwagę na fakt, że spotkanie z kulturą kraju nauczanego języka powinno rozpoczynać się już na pierwszej lekcji języka obcego. Od tego momentu nie należy oddzielać zadań językowych od kultury. Co więcej, to skrzyżowanie kultury i języka musi znaleźć odzwierciedlenie w metodach i koncepcjach nauczania języka obcego oraz materiałach do jego nauki. Cytowany wyżej Lewicki (2005: 248) jest zdania, że języka będącego nierozerwalną częścią kultury nie wolno ograniczać tylko do systemu fonetycznego, semantycznego, gramatycznego, pomijając tło socjokulturowe. Podobne stanowisko prezentuje Altmayer (2005: 154), podkreślając, że akwizycji języka obcego nie można zredukować do przyswojenia umiejętności językowych i sprawności w wąskim rozumieniu, lecz należy pamiętać, że jest ona ściśle związana z przyswajaniem obcokulturowych treści i znaczeń. Bleyhl (1994: 9) idzie jeszcze o krok dalej i określa nauczanie języka uwzględniające tylko jego płaszczyznę lingwistyczną mianem „ułomnego” nauczania.

W myśl powyższych stwierdzeń kultura ${ }^{6}$ powinna być stałym i nieodłącznym elementem każdej lekcji języka obcego. Nie może być ona zatem postrzegana jako tzw. „piąta [niepotrzebna, K.M.] sprawność” (Kramsch

\footnotetext{
${ }^{5} \mathrm{~W}$ wyniku oddzielenia języka od kultury powstaje język sztuczny, jak np. esperanto. Zdaniem Banach (2003: 4) jest to język budowany na bazie terminów i pojęć, które nie mają konkretnych odniesień do kultury. Powoduje to, że trudno w języku pozbawionym korzeni kulturowych wyrażać swoje uczucia i myśli. Autorka zaznaczyła ponadto, że języki schematyczne, oderwane od kultury, a więc sztuczne, nie cieszą się popularnością wśród uczących się.

${ }^{6}$ Kultura postrzegana jako pewien abstrakcyjny system/ogół konceptów, znaczeń, wyobrażeń, wierzeń, postaw, norm oraz wartości preferowanych i przestrzeganych przez członków danej grupy/społeczności, które są zorganizowane w formie kognitywnych schematów i które manifestują się zarówno w zachowaniu członków tej grupy, jak i w produktach wytworzonych przez nich (Maletzke 1996: 6; KnappPotthoff 1997: 184).
} 
1993, w: Strzałka 2005: 372), której rozwijanie na lekcji można sobie darować. Przekonanie, iż kultura jest dodatkiem do lekcji, a nie jej stałym komponentem, godzi w nierozerwalność związku zachodzącego pomiędzy językiem i kulturą. Mimo to wielu nauczycieli języków obcych traktuje kulturę jako suplement, nie zaś jako obligatoryjny element każdej lekcji języka obcego, co pokazały wyniki badań przeprowadzonych wśród polskich nauczycieli języków obcych pracujących w różnych typach szkół (m.in. przez Strzałkę, 2005, Aleksandrowicz-Pędich, 2005, Bandurę, 2007, Szczepaniak-Kozak, 2010). Wielu nauczycieli języków obcych rezygnuje z lekcji o kulturze, ponieważ, na co zwróciła uwagę Wysocka (2003: 72), z jednej strony nie potrafi ich zaplanować i przeprowadzić w języku obcym, z drugiej zaś nie chce ich prowadzić w języku polskim. Na braku nieumiejętności integrowania języka docelowego z ojczystym najbardziej cierpi właśnie interkulturowość.

\section{Podsumowanie}

Teoretyczne rozważania pokazują, że każda lekcja języka obcego jest sama w sobie także lekcją o kulturze. Od nauczyciela zależy więc, na ile świadomie wprowadzi na lekcję elementy szeroko rozumianej kultury uwrażliwiając jednocześnie uczniów na inność oraz utwierdzając ich w przekonaniu, że inny nie tylko nie jest gorszy, ale równie interesujący, stymulujący, wartościowy i twórczy, co swój (Nikitorowicz 2005: 17). Obecnie na lekcjach języków obcych nie można niestety zaobserwować wdrażania wyżej nakreślonej nowej perspektywy edukacyjnej, lecz nieustanne dążenie nauczycieli do tego, aby w ramach swoich lekcji rozwijać u uczniów tylko kompetencję komunikacyjną i językową (ograniczającą się przede wszystkim do pewnej dozy poprawności gramatycznej). Zachowanie ich wynika w dużym stopniu z promowania tychże kompetencji w dokumentach określających kształcenie językowe w Polsce, jak i w powstałych na ich podstawie materiałach do nauczania języków obcych.

Czy pomiędzy dobrą znajomością języka obcego a produkowaniem poprawnych pod względem formalnym zdań i automatycznym, jedynie w pewnym stopniu adekwatnym do danej sytuacji komunikacyjnej, używaniem zwrotów i wzorców językowych można postawić znak równości? Z pewnością nie. Brak wiedzy o kulturze kraju docelowego oraz wiedzy o ogólnym funkcjonowaniu kultur powoduje bowiem, że formułkę rutynową jak będziesz mieć czas, to mnie odwiedź traktujemy jako zaproszenie, na pytanie wie geht's? = co u ciebie słychać? w miejsce oczekiwanej odpowiedzi np. dziękuję, dobrze, opowiadamy ze szczegółami wydarzenia ostatnich dni i miesięcy ${ }^{7}$, że przyjacielski pocałunek w

${ }^{7}$ Podobną sytuację przedstawił Möller (2006: 18-19). 
policzek mało znanego kolegi greckiego pochodzenia postrzegamy jako przejaw nadzwyczajnego zainteresowania naszą osobą ${ }^{8}$, że ciężarnej koleżance z Singapuru ofiarujemy pluszowego bociana ${ }^{9}$, koledze z południowej Francji po dobrze zdanym egzaminie pokażemy palce ułożone $w$ kółko ${ }^{10}$ oraz jesteśmy bardzo zdziwieni, wręcz oburzeni, że Niemiec który zaproponował spotkanie w restauracji nie chce za nas zapłacić ${ }^{11}$. Przytoczone przykłady pokazują, że podczas lekcji języka obcego nie można bagatelizować faktu, że osoba ucząca się tego języka będzie miała w przyszłości do czynienia „z człowiekiem o innej mentalności” (Aleksandrowicz-Pędich, 2007: 53). Bezrefleksyjne realizowanie założeń podejścia komunikacyjnego prowadzi niestety do dość powierzchownego traktowania komponentu kulturowego na lekcjach języka obcego. Żylińska (2003: 55) stwierdza nawet, że w podejściu komunikacyjnym udało się zrobić to, co przecież niemożliwe, a mianowicie "skuteczne oddzielić język od kultury”. Inne zarzuty formułowane pod adresem tego podejścia dotyczą oferowanych treści nauczania (nie tylko w różnych typach szkół, lecz i na kierunkach filologicznych), które charakteryzuje trywializacja szeroko rozumianego pojęcia kultury. Zredukowane zostało ono bowiem do dnia codziennego, rytuałów związanych z witaniem się oraz życia rodzinnego (Althaus, 1999: 27). Zdaniem Żylińskiej (2003: 51) materiał realizowany $w$ ramach lekcji języka obcego sprowadzony został do sucho podanych faktów, teoretycznych i abstrakcyjnych, który został „konsekwentnie 'wyprany' z wszelkich emocji". W szkole przekazywane są zatem tylko treści, konkretna wiedza, nie zaś jej praktyczne zastosowanie. Żylińska (2003) i Altmayer (2005) postulują więc, aby szkoła, w tym szczególnie lekcje języków obcych, przestały mieć w końcu tylko abstrakcyjny wymiar i stały się miejscem,

${ }^{8}$ Grecy witają i żegnają przyjaciół i znajomych całując ich spontanicznie w obydwa policzki. Warto pamiętać o tym, że w Gracji znajomym/znajomą zostaje się już po wspólnie spędzonej godzinie i nie należy się dziwić, że Grek pocałuje nas na pożegnanie (Röttger i Steinhaus 1995: 15).

${ }^{9} \mathrm{~W}$ większości kultur europejskich bocian symbolizuje narodziny dziecka i radość z tym związaną. Dlatego też pary oczekujące dziecka obdarowuje się pluszowymi bocianami, a na kartkach z gratulacjami z okazji narodzin dziecka widnieje często bocian. Takich upominków nie należy jednak robić mieszkańcom Singapuru, bo tam bocian symbolizuje śmierć dziecka podczas połogu (Schröder 2000).

${ }^{10}$ Gest ten interpretowany jest w południowej Francji jako „zero” lub „bez wartości” (Stewart 2005: 138).

11 Problemem często pojawiającym się w relacjach polsko-niemieckich jest mylna interpretacja przez Polaków propozycji wspólnego pójścia do restauracji z zaproszeniem do restauracji. Jeśli Niemiec mówi, że „zaprasza nas do restauracji”, to znaczy, że portfel możemy zostawić w domu. Jeśli zaś proponuje wspólne wyjście do restauracji, to znaczy - idziemy razem, ale każdy płaci za siebie (Mihułka 2010: 256). 
gdzie uczniowie szukają dróg rozwiązywania problemów/konfliktów, jakie mogą pojawić się podczas komunikacji z przedstawicielami innych grup kulturowych w sytuacjach rzeczywistych. Stasiak (2002: 295) podkreśla, że cele nadrzędne realizowane podczas nauczania języków obcych w warunkach zinstytucjonalizowanych powinny obejmować oprócz celów kognitywnych i pragmatycznych, także cele afektywne, które są często bagatelizowane i traktowane jako dodatek do innych celów, a nie cel równorzędny z tymi wyżej nazwanymi. Cele afektywne obejmują emocjonalne rozwijanie zainteresowania dla obcej kultury, kształtowanie umiejętności wychwytywania podobieństw i różnic interkulturowych, wyrabianie wobec nich postaw tolerancji, akceptacji i otwartości.

Jak można więc, na miarę obecnych czasów, zdefiniować zwrot znajomość języka obcego? Osoba mogąca pochwalić się (dobrą) znajomością języka obcego powinna być wyposażona w komplet fundamentalnych kompetencji umożliwiających skuteczne i sprawne komunikowanie się przy użyciu tego języka występującego zarówno jako język obcy jak i lingua franca ${ }^{12}$. Chodzi więc nie tylko o zawsze wymieniane w tym kontekście kompetencje językową i komunikacyjną, lecz także o, niestety często pomijaną, interkulturową, której brak/słaby rozwój, mimo nienagannego opanowania struktur formalnych danego języka, może być przyczyną wielu nieporozumień i konfliktów pojawiających się podczas komunikacji z przedstawicielami odmiennych grup kulturowych.

\section{BIBLIOGRAFIA}

Adamowska, M. 2006. „Ponad milion wyjechało do europracy”. Gazeta Wyborcza. Praca. 23.01.2006:4. Online: http://szukaj.wyborcza.pl/Archiwum/1,0,4565303, 20060123RP-TPR,Ponad_milion_wyjechalo_do_europracy.html DW 02.2012.

Aleksandrowicz-Pędich, L. 2005. Międzykulturowość na lekcjach języków obcych. Białystok: Wydawnictwo Uniwersytetu w Białymstoku.

Aleksandrowicz-Pędich, L. 2006. Rozwijanie kompetencji interkulturowej na studiach biznesowych. Propozycje programowe. Białystok: Wydawnictwo Uniwersytetu w Białymstoku.

Aleksandrowicz-Pędich, L. 2007. „Interkulturowość w kształceniu językowym w Polsce i innych krajach europejskich" (w) Nauczanie języków obcych - Polska a Europa (red. H. Komorowska). Warszawa: Wydawnictwo SWPS Academica: 39-56.

Althaus, H.-J. 1999. „Landeskunde. Anmerkungen zum Stand der Dinge”. Info DaF 26. 1/1999: 25-36.

\footnotetext{
12 Komorowska (2005b: 45) przywołując podział Gnutzmanna (2004) wprowadza rozróżnienie pomiędzy językami międzynarodowymi (w sensie lingua franca) oraz językami obcymi (przy pomocy których komunikujemy się z rodzimymi użytkownikami tego języka).
} 
Altmayer, C. 2005. „Kulturwissenschaftliche Forschung in Deutsch als Fremdsprache. Acht Thesen zu ihrer Konzeption und zukünftigen Entwicklung". Deutsch als Fremdsprache 42. 3: 154-159.

Banach, B. 2003. „Język a kultura”. Języki Obce w Szkole 1: 3-5.

Bandura, E. 2007. Nauczyciel jako mediator kulturowy. Kraków: Krakowskie Towarzystwo Tertium.

Beirat Deutsch als Fremdsprache des Goethe Instituts. 1992. „25 Thesen zur Sprach- und Kulturvermittlung im Ausland". Jahrbuch Deutsch als Fremdsprache 18: 547-551.

Bleyhl, W. 1994. „Das Lernen von Fremdsprachen ist interkulturelles Lernen” (w) Interkulturelles Lernen im Fremdsprachenunterricht. Arbeitspapiere der 14. Frühjahrkonferenz zur Erforschung des Fremdsprachenunterrichts (red. K.-R. Bausch, H. Christ i H.-J. Krumm). Tübingen: Gunther Narr Verlag. (= Giessener Beiträge zur Fremdsprachendidaktik): 9-20.

Bollmann, A. i in. 1998. Interkulturelle Kompetenz als Lernziel. Duisburg: Institut für Ostasienwissenschaften. (= Duisburger Arbeitspapiere Ostasienwissenschaften 17).

Bredella, L. i Christ, H. 1995. „Didaktik des Fremdverstehens im Rahmen einer Theorie des Lehrens und Lernens einer Fremdsprache" (w) Didaktik des Fremdverstehens (red. L. Bredella i H. Christ). Tübingen: Gunter Narr Verlag: 8-19.

Byram, M. 1997. Teaching and Assessing Intercultural Communicative Competence. Clevedon: Multilingual Matters.

Byram, M. 2005. „Europejskie portfolio językowe - Model teoretyczny i propozycja wzoru biografii "kluczowych doświadczeń interkulturowych'”. Języki Obce w Szkole 5: 59-68.

Centrum Badania Opinii Społecznej, http://www.cbos.pl DW 02.2012. BS/177/2006. Znajomość języków obcych i wyjazdy zagraniczne.

Erll, A. i Gymnich, M. 2007. Interkulturelle Kompetenzen. Erfolgreich kommunizieren zwischen Kulturen. Stuttgart: Klett Lernen und Wissen.

Göhring, H. 1980. „Deutsch als Fremdsprache und interkulturelle Kommunikation” (w) Fremdsprache Deutsch. Grundlagen und Verfahren der Germanistik als Fremdsprachenphilologie. Tom 1. (red. A. Wierlacher). München: Wilhelm Fink Verlag: 70-90.

Heyd, G. 1997. Aufbauwissen für den Fremdsprachenunterricht (DaF). Ein Arbeitsbuch. Kognition und Konstruktion. Tübingen: Gunter Narr Verlag.

Knapp-Potthoff, A. 1997. „Interkulturelle Kommunikationsfähigkeit als Lernziel” (w) Aspekte interkultureller Kommunikationsfähigkeit (red. A. Knapp-Potthoff i M. Liedke). München: Iudicium Verlag: 181-205.

Komorowska, H. 2005a. Metodyka nauczania języków obcych. Warszawa: Fraszka Edukacyjna.

Komorowska, H. 2005b. „Testowanie językowych osiągnięć uczniów - trudności i zagrożenia”. Języki Obce w Szkole 6: 41-51.

Krumm, H.-J. 1994. „Mehrsprachigkeit und interkulturelles Lernen. Orientierungen im Fach Deutsch als Fremdsprache”. Jahrbuch Deutsch als Fremdsprache 20: 13-36.

Lewicki, R. 2005. „(Inter)kulturelle Dimension der Glottodidaktik” (w) Germanistische Erfahrungen und Perspektiven der Interkulturalität. Materialien der Jahrestagung 
des Verbandes Polnischer Germanisten 22.-24. April 2005. (red. F. Grucza, H.-J. Schwenk i M. Olpińska). Kraków, Warszawa: euro edukacja: 248-252.

Liedtke, H. 2006. „Was unmoralische Engländerinnen, der Präsident der Vereinigten Staaten von Amerika und Sojasauce gemeinsam haben". Materialien Deutsch als Fremdsprache 76: 151-170.

Lubecka, A. 1998. „Interkulturowa kompetencja komunikatywna - jak wykorzystać gry symulacyjne do jej osiągnięcia”. Biuletyn glottodydaktyczny 4: 59-74.

Maletzke, G. 1996. Interkulturelle Kommunikation. Zur Interaktion zwischen Menschen verschiedener Kulturen. Opladen: Westdeutscher Verlag.

Mihułka, K. 2010. „Nieporozumienia natury werbalnej i niewerbalnej podczas spotkań interkulturowych" (w) Kompetencja interkulturowa w teorii i praktyce edukacyjnej (red. M. Mackiewicz). Poznań: Wydawnictwo Wyższej Szkoły Bankowej: 253-262.

Mihułka, K. 2012. Rozwój kompetencji interkulturowej w warunkach szkolnych - mity a polska rzeczywistość. Na przykładzie języka niemieckiego jako L3. Rzeszów: Wydawnictwo Uniwersytetu Rzeszowskiego.

Möller, S. 2006. Polska da się lubić. Mój prywatny przewodnik po Polsce i Polakach. Poznań: Wydawnictwo Publicat.

Myczko, K. 2005. „Kompetencja interkulturowa jako cel kształcenia językowego” (w) Dydaktyka języków obcych a kompetencja kulturowa i komunikacja interkulturowa (red. M. Mackiewicz). Poznań: Wydawnictwo Wyższej Szkoły Bankowej: 27-35.

Nikitorowicz, J., 2005. „Próba określenia przedmiotu edukacji międzykulturowej” (w) Region - tożsamość - edukacja (red. J. Nikitorowicz, D. Misiejuk i M. Sobecki). Białystok: Trans humana: 15-33.

Röttger, E. i Steinhaus, M. 1995. „Missverständnisse in griechisch-deutscher interkultureller Kommunikation". Info DaF 22. 1/1995: 3-18.

Schröder, H., 2000, „Tabu” Online: http://tabu.sw2.euv-frankfurt-o.de/Tabu_pdf/tabu.pdf, 1-12 DW 03.2004.

Stasiak, H. 2002. „Nauczanie języka niemieckiego jako drugiego języka obcego po angielskim - konsekwencje dla kształcenia nauczycieli" (w) European year of languages 2001. (red. T. Siek-Piskozub). Poznań: Wydawnictwo Naukowe UAM: 291-302.

Stewart, J. 2005. Mosty zamiast murów. Podręcznik komunikacji interpersonalnej. Warszawa: Wydawnictwo PWN.

Strzałka, A. 2005. „Rozwijanie pedagogicznej świadomości interkulturowej przyszłych i obecnych nauczycieli języka angielskiego" (w) Język trzeciego tysiq̨clecia III. Język polski i języki obce - kontakty, kultura, dydaktyka. Tom 3 (red. M. Dąbrowska). Kraków: Krakowskie Towarzystwo „Tertium”: 371-379.

Szczepaniak-Kozak, A. 2010. „Interkulturowa kompetencja komunikacyjna z perspektywy nauczyciela języka angielskiego" (w) Kompetencja interkulturowa w teorii i praktyce (red. M. Mackiewicz). Poznań: Wydawnictwo Wyższej Szkoły Bankowej: 125-135.

Volkmann, L. 2002. „Aspekte und Dimensionen interkultureller Kompetenz” (w) Interkulturelle Kompetenz. Konzepte und Praxis des Unterrichts (red. L. Volkmann, K. Stierstorfer i W. Gehring). Tübingen: Gunter Narr Verlag: 11-47. 
Wilczyńska, W. 2005. „Czego trzeba do udanej komunikacji interkulturowej” (w) Dydaktyka języków obcych a kompetencja kulturowa i komunikacja interkulturowa (red. M. Mackiewicz). Poznań: Wydawnictwo Wyższej Szkoły Bankowej: 15-26.

Wysocka, M. 2003. Profesjonalizm w nauczaniu języków obcych. Katowice: Wydawnictwo Uniwersytetu Śląskiego.

Żylińska, M. 2003. „Podejście interkulturowe, czyli o konieczności zmian w nauczaniu języków obcych". Języki Obce w Szkole 6: 49-62. 